\title{
Application of Mental Nursing Care For Mr.K with Risk of Violence Behavior
}

\author{
Yola Hermanisa \\ yolahermanisamt20@gmail.com
}

\section{BAB 1}

\section{PENDAHULUAN}

\subsection{Latar Belakang}

Skizofrenia merupakan sekelompok reaksi psikotik yang mempengaruhi berbagai bidang fungsi individu, termasuk pemikiran, berkomunikasi, menerima, menafsirkan realitas, perasaan, dan menunjukkan emosi karena skizofrenia kronis, penyakit parah, dan melumpuhkan, kelainan otak yang ditandai oleh pikiran kacau, delusi, halusinasi, dan aneh tingkah laku (Pardede, \& Laia. 2020; Pardede \& Ramadia, 2021). Skizofrenia merupakan suatu gangguan jiwa berat yang bersifat berat dan kronis yang menyerang 20 juta orang di seluruh dunia (WHO, 2019). Skizofrenia adalah gangguan jiwa yang dapat berakhir dengan hilanngya dengan nyawa seseorang. Dalam penanganan penyakit ini karena jiwa yang terganggu maka di butuhkan adalah terapi, rehabilitasi serta dengan konseling. Upaya terbesar untuk penangan penyakit gangguan jiwa terletak pada keluarga dan masyarakat, dalam hal ini terapi terbaik adalah bentuk dukungan keluarga dalam mencegah kambuhnya penyakit skizofrenia (Pitayanti, \& Hartono, 2020).

Tanda dan gejala yang timbul akibat skizofrenia berupa gejala positif dan negatif seperti perilaku kekerasan. Resiko perilaku kekerasan merupakan salah satu respon marah yang diespresikan dengan melakukan ancaman, mencederai diri sendiri maupun orang lain. Pada aspek fisik tekanan darah meningkat, denyut nadi dan pernapasan meningkat, marah, mudah tersinggung, mengamuk dan bisa mencederai diri sendiri. Perubahan pada fungsi kognitif, fisiologis, afektif, hingga perilaku dan sosial hingga 
menyebabkan resiko perilaku kekerasan. Berdasarkan data tahun 2017 dengan resiko perilaku kekerasan sekitar $0,8 \%$ atau dari 10.000 orang menunjukkan resiko perilaku kekerasan sanggatlah tinggi (Pardede, 2020).

Perilaku kekerasan merupakan salah satu respon terhadap streesor yang dihadapi oleh seseorang, respon ini dapat menimbulkan kerugian baik kepada diri sendiri, orang lain, maupun lingkungan. Seseorang yang mengalami perilaku kekerasan sering menunjukan perubahan perilaku seperti mengancam, gaduh, tidak bisa diam, mondar-mandir, gelisah, intonasi suara keras, ekspresi tegang, bicara dengan semangat, agresif, nada suara tinggi dan bergembira secara berlebihan. Pada seseorang yang mengalami resiko perilaku kekerasan mengalami perubahan adanya penurunan kemampuan dalam memecahkan masalah, orientasi terhadap waktu, tempat dan orang serta gelisah (Pardede, Siregar, \& Halawa, 2020). Risiko mencederai merupakan suatu tindakan yang memungkinkan dapat melukai atau membahayakan diri sendiri, orang lain, dan lingkungan sehingga masalah yang terjadi pada pasien parilaku kekerasan akan melibatkan keluarga (Suryeti, 2017).

Survei awal pada pembuatan asuhan keperawatan jiwa pada skizofrenia dengan masalah risiko perilaku kekerasan dilakukan di Yayasan Pemenang Jiwa Sumatera dengan pasien nama inisial Tn.K, klien datang ke yayasan di bawa keluarga klien karena awalnya klien sering marah-marah dan mengamuk tidak jelas.

\subsection{Rumusan Masalah}

Berdasarkan latar belakang masalah tersebut maka dapat dirumuskan masalah sebagai berikut : Bagaimana Memberikan Asuhan Keperawatan Jiwa Pada Tn. K dengan Risiko Perilaku Kekerasan di Yayasan pemenang jiwa Sumatera.

\subsection{Tujuan Penulisan}

Adapun tujuannya sebagai berikut : 


\subsubsection{Tujuan Umum}

Penulis mampu memberikan asuhan keperawatan jiwa pada Tn. K dengan Risiko Perilaku Kekerasan di Yayasan pemenang jiwa Sumatera.

\subsubsection{Tujuan Khusus}

a. Mahasiswa mampu mengetahui defenisi, tanda \& gejala,faktor penyebab, mekanisme koping, penatalaksanaan pada pasien dengan Risiko Perilaku Kekerasan

b. Mahasiswa mampu melakukan pengkajian pada pasien dengan Risiko Perilaku Kekerasan.

c. Mahasiswa mampu menegakkan diagnosa atau masalah keperawatan pada Tn. K dengan Risiko Perilaku Kekerasan.

d. Mahasiswa mampu menetapkan intervensi keperawatan secara menyeluruh pada Tn. K dengan Risiko Perilaku Kekerasan.

e. Mahasiswa mampu melakukan tindakan keperawatan yang nyata pada Tn. K dengan Risiko Perilaku Kekerasan.

f. Mahasiswa mampu mengevaluasi sebagai tolak ukur guna menerapkan asuhan keperawatan pada Tn.K dengan Risiko Perilaku Kekerasan.

g. Mahasiswa mampu mendokumentasikan asuhan keperawatan pada Tn. K dengan Risiko Perilaku Kekerasan. 


\section{BAB 2 \\ TINJAUAN TEORITIS}

\subsection{Pengertian}

Perilaku kekerasan merupakan respon maladaptif dari kemarahan, hasil dari kemarahan yang ekstrim ataupun panik. Perilaku kekerasan yang timbul pada klien skizofrenia diawali dengan adanya perasaan tidak berharga, takut,dan ditolak oleh lingkungan sehingga individu akan menyingkir dari hubungan interpersonal dengan oran lain (Pardede, Keliat \& Yulia, 2015).

Perilaku kekerasan adalah salah satu respon terhadap stressor yang dihadapi oleh seseorang yang dihadapi oleh seeorang yang di tunjukan dengan perilaku kekerasan baik pada diri sediri maupun orang lain dan lingkungan baik secara verbal maupun non-verbal. Bentuk perilaku kekerasan yang dilakukan bisa amuk, bermusuhan yang berpotensi melukai, merusak baik fisik maupun kata-kata (Kio, Wardana \& Arimbawa, 2020).

Perilaku kekerasan adalah suatu bentuk perilaku yang bertujuan melukai seseorang secara fisik maupun psikologis dapat terjai dalam dua bentuk yaitu saat berlangsung kekerasan atau riwayat perilaku kekerasan. Perilaku kekerasan merupakan respon maladaptif dari marah akibat tidak mampu klien untuk mengatasi strssor lingkungan yang dialaminya (Estika, 2021).

\subsection{Rentang Respon Marah}


Asertif Frustasi Pasif Agresif Amuk

\section{Gambar 2.1 Rentang Respon Marah}

Ket :

1. Assertif adalah mengungkapkan marah tanpa menyakiti, melukai perasaan orang lain, atau tanpa merendahkan harga diri orang lain.

2. Frustasi adalah respon yang timbul akibat gagal mencapai tujuan atau keinginan. Frustasi dapat dialami sebagai suatu ancaman dan kecemasan. Akibat dari ancaman tersebut dapat menimbulkan kemarahan.

3. Pasif adalah respon dimana individu tidak mampu mengungkapkan perasaan yang dialami.

4. Agresif merupakan perilaku yang menyertai marah namun masih dapat dikontrol oleh individu. Orang agresif bisaanya tidak mau mengetahui hak orang lain. Dia berpendapat bahwa setiap orang harus bertarung untuk mendapatkan kepentingan sendiri dan mengharapkan perlakuan yang sama dari orang lain.

5. Amuk adalah rasa marah dan bermusuhan yang kuat disertai kehilangan control diri. Pada keadaan ini individu dapat merusak dirinya sendiri maupun terhadap orang lain.

\subsection{Faktor Terjadinya Perilaku Kekerasan}

\subsubsection{Faktor Predisposisi}

Menurut Yusuf (2015), terdapat faktor predisposisi dan faktor presipitasi terjadinya perilaku kekerasan, yaitu:

\section{a. Psikoanalisis}

Teori ini menyatakan bahwa perilaku agresif merupakan hasil dari dorongan insting

\section{b. Psikologis}


Berdasarkan teori frustasi-agresif, agresivitas timbul sebagai hasil dari peningkatan frustasi. Tujuan tidak tercapai dapat menyebabkan frustasi berkepanjangan.

c. Biologis

Bagian-bagian otak yang berhubungan dengan terjadinya agresivitas sebagai berikut: (Stuart, 2016). 


\section{d. Sistem limbik}

Merupakan organ yang mengatur dorongan dasar dan ekspresi emosi serta perilaku seperti makan, agresif dan respons seksual.Selain itu, mengatur, mengatur sistem informasi dan memori.

\section{e. Lobus temporal}

Organ yang berfungsi sebagai penyimpan memori dan melakukan interpretasi pendengaran.

\section{f. Lobus frontal}

Organ yang berfungsi sebagai bagian pemikiran yang logis, serta pengelolaan emosi dan alasan berpikir.

\section{g. Neurotransmiter}

Beberapa neurotransmiter yang berdampak pada agresivitas adalah serotonin, Dopamin, Neropineprin, Acetylcholine dan GABA.

\section{h. Perilaku}

1. Kerusakan organ otak, retardasi mental dan gangguan belajar mengakibatkan kegagalan kemampuan dalam berespon positif terhadap frustasi.

2. Penekanan emosi berlebihan pada anak-anak atau godaan orang tua memengaruhi kepercayaan dan percaya diri individu.

3. Perilaku kekerasan di usia muda, baik korban kekerasan pada anak atau mengobservasi kekerasan dalam keluarga mempengaruhi penggunaan kekerasan sebagai koping.

\section{i. Sosial Kultural}

1. Norma merupakan kontrol masyarakat pada kekerasan. Hal ini mendefinisikan ekspresi perilaku kekerasan yang diterima atau tidak diterima akan menimbulkan sanksi.

2. Budaya asertif di masyartakat membantu individu yang berespon terhadap marah yang sehat. 


\subsubsection{Faktor Presipitasi}

Faktor presipitasi dapat bersumber dari klien, lingkungan atau interaksi dengan orang lain. Kondisi klien seperti kelemahan fisik, keputusasaan, ketidakberdayaan, percaya diri yang kurang dapat menjadi perilaku kekerasan. Demikian pula dengan situasi lingkungan yang ribut, padat, kritikan yang mengarah pada penghinaan, kehilangan orang yang dicintai atau pekerjaan dan kekerasan merupakan faktor penyebab lain (Parwati, Dewi \& Saputra 2018).

\subsection{Tanda Dan Gejala}

Menurut Keliat (2016), tanda dan gejala perilaku kekerasan sebagai berikut :

1. Emosi: tidak adekuat, tidak aman, rasa terganggu, marah (dendam), dan jengkel

2. Intelektual: mendominasi, bawel, sarkasme, berdebat, dan meremehkan

3. Fisik: muka merah, pandangan tajam, napas pendek, keringat, sakit fisik, penyalahgunaan zat, tekanan darah meningkat

4. Spiritual: kemahakuasaan, kebijakan/kebenaran diri, keraguan, tidak bermoral, kebejatan, kreativitas terlambat.

5. Sosial : menarik diri, pengasingan, penolakan, kekerasan, ejekan, dan humor.

\subsection{Mekanisme Koping}

Menurut Prastya \& Arum (2017). Perawat perlu mengidentifikasi mekanisme koping klien, sehingga dapat membantu klien untuk mengembangkan koping yang konstruktif dalam mengekpresikan kemarahannya.Mekanisme koping yang umum digunakan adalah mekanisme pertahanan ego seperti displacement, sublimasi, proyeksi, represif, denial dan reaksi formasi. 
Perilaku yang berkaitan dengan risiko perilaku kekerasan antara lain:

a. Menyerang atau menghindar

Pada keadaan ini respon fisiologis timbul karena kegiatan system syaraf otonom bereaksi terhadap sekresi epinefrin yang menyebabkan tekanan darah meningkat, takikardi, wajah marah, pupil melebar, mual, sekresi HCL meningkat, peristaltik gaster menurun, kewaspadaan juga meningkat, tangan mengepal, tubuh menjadi kaku dan disertai reflek yang cepat.

b. Menyatakan secara asertif

Perilaku yang sering ditampilkan individu dalam mengekspresikan kemarahannya yaitu dengan perilaku pasif, agresif dan perilaku asertif adalah cara yang terbaik, individu dapat mengekspresikan rasa marahnya tanpa menyakiti orang lain secara fisik maupun psikologis dan dengan perilaku tersebut individu juga dapat mengembangkan diri.

c. Memberontak

Perilaku muncul biasanya disertai kekerasan akibat konflik perilaku untuk menarik perhatian orang lain.

d. Perilaku kekerasan

Tindakan kekerasan atau amuk yang ditujukan akibat konflik perilaku untuk menarik perhatian orang lain.

\subsection{Penatalaksanaan}

Yang diberikan pada klien yang mengalami gangguan jiwa amuk ada 2 yaitu:

1. Medis

a. Nozinan, yaitu sebagai pengontrol perilaku psikososial.

b. Halloperidol, yaitu mengontrol psikosis dan prilaku merusak diri.

c. Thrihexiphenidil, yaitu mengontro perilaku merusak diri dan menenangkan hiperaktivitas.

d. ECT (Elektro Convulsive Therapy), yaitu menenangkan klien bila mengarah pada keadaan amuk. 
2. Penatalaksanaan keperawatan
a. Psikoterapeutik
b. Lingkungan terapieutik
c. Kegiatan hidup sehari-hari (ADL)
d. Pendidikan kesehatan

\subsection{Konsep Dasar Keperawatan}

\subsubsection{Pengkajian}

1. Identitas

Nama, umur, jenis kelamin, No MR, tanggal masuk RS, tangal pengkajian.

2. Alasan masuk

Biasanya klien masuk dengan alasan sering mengamuk tanpa sebab, memukul, membanting, mengancam, menyerang orang lain, melukai diri sendiri, mengganggu lingkungan, bersifat kasar dan pernah mengalami gangguan jiwa dimasa lalu kambuh karena tidak mau minum obat secara teratur (Keliat,2016).

3. Faktor Predisposisi

a. Biasanya klien pernah mengalami gangguan jiwa pada masa lalu dan pernah dirawat atau baru pertama kali mengalami gangguan jiwa (Parwati, Dewi \& Saputra 2018).

b. Biasanya klien berobat untuk pertama kalinya kedukun sebagai alternative serta memasung dan bila tidak berhasil baru di bawa kerumah sakit jiwa.

c. Trauma. Biasnya klien pernah mengalami atau menyaksikan penganiayaan fisik, seksual, penolakan, dari lingkungan.

d. Biasanya ada anggota keluarga yang mengalami gangguan jiwa, kalau ada hubungan dengan keluarga, gejala, pengobatan dan perawatan.

e. Biasanya klien pernah mengalami pengalaman masa lalu yang tidak menyenangkan misalnya, perasaan ditolak, dihina, dianiaya, penolakan dari lingkungan 
4. Fisik

Pengkajian fisik

a. Ukur dan observasi tanda-tanda vital seperti tekanan darah akan bertambah naik, nadi cepat, suhu, pernapasan terlihat cepat.

b. Ukur tinggi badan dan berat badan.

c. Yang kita temukan pada klien dengan prilaku kekerasan pada saat pemeriksaan fisik (mata melotot, pandangan tajam, tangan mengepal, rahang mengatup, wajah memerah)

d. Verbal (mengancam, mengupat kata-kata kotor, berbicara kasar dan ketus).

5. Psikososial

a. Genogram

Genogram dibuat 3 generasi keatas yang dapat menggambarkan hubungan klien dengan keluarga. Tiga generasi ini dimaksud jangkauan yang mudah diingat oleh klien maupun keluarga apa disaat pengkajian.

b. Konsep diri

Biasanya ada anggota tubuh klien yang tidak disukai klien yang mempengaruhi keadaan klien saat berhubungan dengan orang lain sehingga klien merasa terhina, diejek dengan kondisinya tersebut.

c. Identitas

Biasanya pada klien dengan prilaku kekerasan tidak puas dengan pekerjaannya, tidak puas dengan statusnya, baik disekolah, tempat kerja dan dalam lingkungan tempat tinggal

d. Harga diri

Biasanya klien dengan risiko prilaku kekerasan hubungan dengan orang lain akan terlihat baik, harmoni sata terdapat penolakan atau klien merasa tidak berharga, dihina, diejek dalam lingkungan keluarga maupun diluar lingkungan keluarga. 
1. Peran diri

Biasanya klien memiliki masalah dengan peranatau tugas yang diembannya dalam keluarga, kelompok atau masyarakat dan biasanya klien tidak mampu melaksanakan tugas dan peran tersebut dan merasa tidak berguna.

2. Ideal diri

Biasanya klien memilki harapan yang tinggi terhadap tubuh, posisi dan perannya baik dalam keluarga, sekolah, tempat kerja dan masyarakat.

6. Hubungan sosial

a. Orang yang berarti Tempat mengadu, berbicara

b. Kegiatan yang diikuti klien dalam masyarakat dan apakah klien berperan aktif dalam kelompok tersebut

c. Hambatan dalam berhubungan dengan orang lain/tingkat keterlibatan klien dalam hubungan masyarakat.

7. Spiritual

a. Nilai dan keyakinan

Biasanya klien mengatakan bahwa dia tidak mengalami gangguan jiwa.

b. Kegiatan ibadah

c. Biasaya dalam selama sakit klien jarang melakukan ibadah.

8. Status mental

a. Penampilan.

b. Biasanya penampilan klien kotor.

c. Pembicaraan.

d. Biasanya pada klien prilaku kekerasan pada saat dilakukan pengkajian bicara cepat,keras, kasar, nada tinggi dan mudah tersinggung.

e. Aktivitas motorik

f. Biasanya aktivitas motoric klien dengan prilaku kekerasan akan terlihat tegang, gelisah, gerakan otot muka berubahubah, gemetar, tangan mengepal, dan rahang dengan kuat. 
g. Alam perasaan

Biasanya akan merasa sedih dan menyesali apa yang telah dilakukan

h. Efek

Biasanya klien mudah tersinggung dan sering marah-marah tanpa sebab

i. Interaksi selama wawancara

Biasanya klien dengan risiko prilaku kekerasan akan terlihat bermusuhan, curiga, tidak kooperatif, tidak mau menatap lawan bicara dan mudah tersinggung.

j. $\quad$ Persepsi

Biasanya klien dengan prilaku kekerasan masih dapat menjawab pertanyaan dengan jelas.

k. Isi Pikir

Biasanya klien meyakini dirinya tidak sakit, dan baik-baik saja.

1. Tingkat kesadaran

Biasanya klien prilaku kekerasan kadang tampak bingung,

m. Memori

Biasanya klien diwaktu wawancara dapat mengingat kejadian yang terjadi dan mengalami gangguan daya ingat jangka panjang.

n. Kemampuan penilaian

Biasanya klien mengalami kemampuan penilaian ringan dan sedang dan tidak mampu mengambil keputusan

o. Daya fikir diri

Biasanya klien mengingkari penyakit yang dideritanya

9. Kebutuhan persiapan pulang

a. Makan

Biasanya klien tidak mengalami perubahan

b. BAB/BAK

Biasanya klien dengan risiko prilaku kekerasan tidak ada gangguan 
c. Mandi

Biasanya klien jarang mandi, tidak menyikat gigi, jarang mencuci rambut dan bercukur atau berhias. Badan klien sangat bau dan kotor, dan klien hanya melakukan kebersihan diri jika disuruh.

d. Berpakaian

Biasanya klien jarang mengganti pakaian, dan tidak mau berdandan. Klien tidak mampu mengenakan pakaian dengan sesuai dan klien tidak mengenakan alas kaki

e. Istirahat dan tidur

Biasanya klien tidak melakukan persiapan sebelum tidur, seperti: menyikat gigi, cucu kaki, berdoa. Dan sesudah tidur seperti: merapikan tempat tidur, mandi atau cuci muka dan menyikat gigi. Frekuensi tidur klien berubah-ubah, kadang nyenyak dan kadang gaduh atau tidak tidur.

f. Penggunaan obat

Biasanya klien mengatakan minum obat 3 kali sehari dan klien tidak mengetahui fungsi obat dan akibat jika putus minum obat.

g. Pemeliharaan kesehatan

Biasanya klien tidak memperhatikan kesehatannya, dan tidak peduli tentang bagaimana cara yang baik untuk merawat dirinya.

h. Aktifitas didalam rumah

Biasanya klien mampu merencanakan, mengolah, dan menyajikan makanan, merapikan rumah, mencuci pakaian sendiri dan mengatur biaya sehari-hari.

10. Mekanisme koping

Biasanya klien menggunakan respon maldaptif yang ditandai dengan tingkah laku yang tidak terorganisir, marah-marah bila 
keinginannya tidak terpenuhi, memukul anggota keluarganya, dan merusak alat-alat yg ada dirumah.

11. Masalah psikologis dan lingkungan

Biasanya klien merasa ditolak dan mengalami masalah interaksi dengan lingkungan

12. Pengetahuan

Biasanya klien dengan prilaku kekerasan kurang pengetahuan tentang penyakitnya,dan klien tidak mengetahui akibat dari putus obat dan fungsi Dari obat yang diminumnya.

\subsubsection{Diagnosa Keperawatan}

Menurut NANDA 2015-2017 yakni gangguan persepsi. Dengan faktor berhubungan dan batasan karakteristik disesuaikan dengan keadaan yang ditemukan pada tiap-tiap partisipan. Topik yang diteliti yakni kemampuan mengontrol RPK (Aji, 2019).

\subsubsection{Perencanaan Keperawatan}

Rencana tindakan pada keluarga (Keliat, 2014) adalah ;

1. Diskusikan masalah yang dihadap keluarga dalam merawat pasien

2. Berikan penjelasan meliputi : pengertian RPK, proses terjadinya RPK, jenis RPK yang dialami, tanda dan gejala RPK, proses terjadinya RPK.

3. Jelaskan dan latih cara merawat anggota keluarga yang mengalami RPK : menghardik, minum obat, bercakap-cakap, melakukan aktivitas.

4. Diskusikan cara menciptakan lingkungan yang dapat mencegah terjadinya RPK.

5. Diskusikan tanda dan gejala kekambuhan

6. Diskusikan pemanfaatan fasilitas pelayanan kesehatan terdekat untuk follow up anggota keluarga dengan RPK. 
Rencana tindakan keperawatan pada klien dengan diagnosa gangguan persepsi sensori RPK meliputi pemberian tindakan keperawatan berupa terapi (Sulah, Pratiwi, \& Teguh. 2016) yaitu :

1. Bantu klien mengenal RPKnya meliputi isi, waktu terjadi RPK, isi, frekuensi, perasaan saat terjadi RPK respon klien terhadap RPK

mengontrol RPK dengan cara menghardik,

2. meminum obat secara teratur.

3. Melatih bercakap-cakap dengan orang lain,

4. Menyusun kegiatan terjadwal dan aktifitas

\subsubsection{Implementasi}

Implementasi disesuaikan dengan rencana tindakan keperawatan. Pada situasi nyata sering pelaksanaan jauh berbeda dengan rencana, hal ini terjadi karena perawat belum terbiasa menggunakan rencana tertulis dalam melaksanakan tindakan keperawatan. Sebelum melaksanakan tindakan keperawatan yang sudah direncanakan, perawat perlu memvalidasi dengan singkat apakah rencana tindakan masih sesuai dan dibutuhkan klien sesuai dengan kondisinya (here and now). Perawat juga menilai diri sendiri, apakah kemampuan interpersonal, intelektual, tekhnikal sesuai dengan tindakan yang akan dilaksanakan, dinilai kembali apakah aman bagi klien. Setelah semuanya tidak ada hambatan maka tindakan keperawatan boleh dilaksanakan (Sahputra, 2021)

Adapun pelaksanaan tindakan keperawatan jiwa dilakukan berdasarkan Strategi Pelaksanaan (SP) yang sesuai dengan masingmasing masalah utama. Pada masalah gangguan sensori persepsi: RPK pendengaran, terdapat 2 jenis SP, yaitu SP Klien dan SP Keluarga.SP klien terbagi menjadi SP 1 (membina hubungan saling percaya, mengidentifikasi RPK “jenis, isi, waktu, frekuensi, situasi, perasaan dan respon RPK", mengajarkan cara menghardik, 
memasukan cara menghardik ke dalam jadwal; SP 2 (mengevaluasi SP 1, mengajarkan cara minum obat secara teratur, memasukan ke dalam jadwal); SP 3 (mengevaluasi SP 1 dan SP 2, menganjurkan klien untuk mencari teman bicara); SP 4 (mengevaluasi SP 1, SP 2, dan SP 3, melakukan kegiatan terjadwal).

SP keluarga terbagi menjadi SP 1 (membina hubungan saling percaya, mendiskusikan masalah yang dihadapi keluarga dalam merawat pasien, menjelaskan pengertian, tanda dan gejala helusinasi, jenis RPK yang dialami klien beserta proses terjadinya, menjelaskan cara merawat pasien RPK); SP 2 (melatih keluarga mempraktekan cara merawat pasien dengan RPK, melatih keluarga melakukan cara merawat langsung kepada pasien RPK); SP 3 (membantu keluarga membuat jadwal aktivitas di rumah termasuk minum obat (discharge planing), menjelaskan follow up pasien setelah pulang). Pada saat akan dilaksanakan tindakan keperawatan maka kontrak dengan klien dilaksanakan dengan menjelaskan apa yang akan dikerjakan dan peran serta klien yang diharapkan, dokumentasikan semua tindakan yang telah dilaksanakan serta respon klien.

\subsubsection{Evaluasi Keperawatan}

Evaluasi adalah proses hasil atau sumatif dilakukan dengan membandingkan respon klien pada tujuan umum dan tujuan khusus yang telah ditentukan RPK tidak terjadi perilaku kekerasan, klien dapat membina hubungan saling percaya, klien dapat mengenal RPKnya, klien dapat mengontrol RPK dari jangka waktu 4x24 jam didapatkan data subjektif keluarga menyatakan senang karena sudah diajarkan teknik mengontrol RPK, keluarga menyatakan pasien mampu melakukan beberapa teknik mengontrol RPK. Data objektif pasien tampak berbicara sendiri saat RPK itu datang, pasien dapat berbincang-bincang dengan orang lain, pasien mampu melakukan aktivitas terjadwal, dan minum obat secara teratur (Aji, 2019) 


\section{BAB 3}

\section{TINJAUAN KASUS}

\subsection{Identitas Klien}

$\begin{array}{ll}\text { Inisial } & : \text { Tn.K } \\ \text { Jenis kelamin } & : \text { Laki-Laki } \\ \text { Umur } & : \text { T5 Tahun } \\ \text { Agama } & : \text { Budha } \\ \text { Status } & : \text { Lajang } \\ \text { Tanggal pengkajian } & \text { : } 4 \text { Maret } 2021 \\ \text { Informant } & : \text { Status klien dan komunikasi dengan klien. }\end{array}$

\subsection{Alasan Masuk}

Alasan klien masuk yayasan pemenangan jiwa adalah klien mengatakan klien sering marah-marah, melempar barang yang ada dirumahnya, klien mengatakan pernah memukul adik dan orang sekitarnya.

\subsection{Faktor Predisposisi}

Klien sebelumnya pernah mengalami gangguan jiwa \pm 1 tahun yang lalu tepatnya pada tahun 2017 dan pulang kerumah dalam keadaan tenang. Di rumah klien tidak rutin minum obat, sehingga timbul gejala-gejala seperti diatas. Keluarga klien tidak ada yang pernah mengalami gangguan jiwa.

Masalah Keperawatan: Resiko Perilaku kekerasan

\subsection{Fisik}

Klien tidak memiliki keluhan fisik, saat dilakukan pemeriksaan tanda-tanda vital, didapatkan hasil TD : 130/90 mmHg ; $\mathrm{N}: 85 \mathrm{x} / \mathrm{i} ; \mathrm{S}: 36,5^{\circ} \mathrm{C} ; \mathrm{P}: 20 \mathrm{x} / \mathrm{i}$. Klien memiliki tinggi badan $170 \mathrm{~cm}$ dan berat badan $68 \mathrm{Kg}$. 


\subsection{Psikososial}

\subsubsection{Genogram}

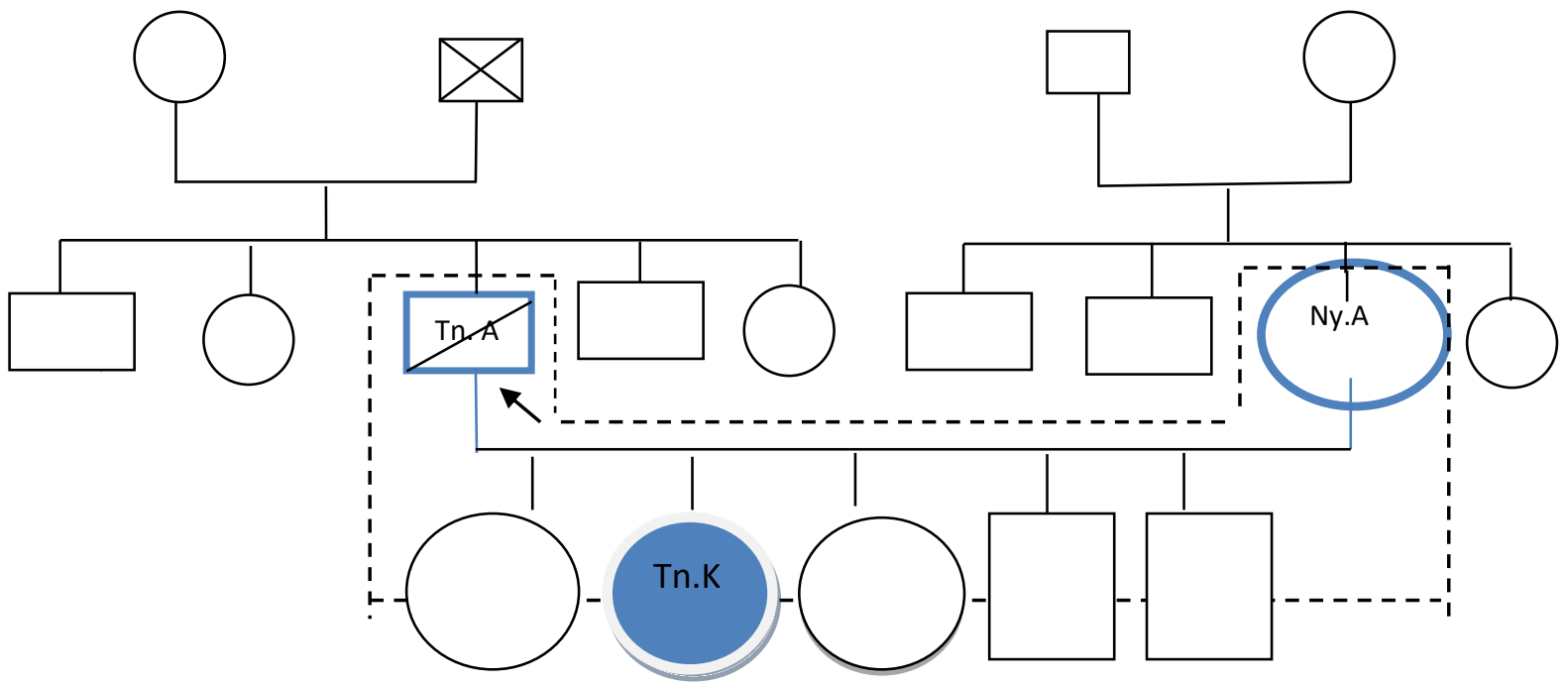

Gambar 3.1 Genogram

Penjelasan :

Klien anak kedua dari 5 bersaudara, klien berinisial Tn.K ,anak yatim ayahnya meninggal sekitar 4 tahun yg lalu.

Keterangan :

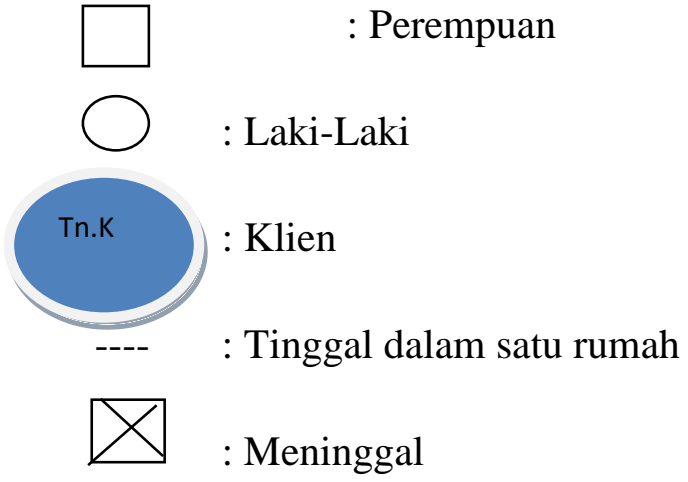

\subsubsection{Konsep diri}

a. Gambaran diri : Tidak ada kecacatan

b. Identitas : Klien anak ke 2 dari 5 bersaudara, klien hanya lulusan SMA yang saat ini dirawat di yayasan pemenang jiwa medan

c. Peran : Klien berperan sebagai anak dan masih lajang, klien sebelumya tinggal bersama keluarganya. 
d. Ideal diri : Klien merasa malu karena di antarkan ke yayasan pemenangan jiwa tersebut

e. Harga diri : Klien merasa tidak berguna menjadi abang, karena dirinya berada jauh dari abang,adik dan orangtuanya.

Masalah keperawatan :Gangguan konsep diri : harga diri rendah

\subsubsection{Hubungan sosial}

Klien menggatakan bahwa keluarganya adalah orang yang sangat berarti dalam hidupnya, terutama orangtuanya. Klien selalu mengikuti kegiatan di yayasan tersebut dan membantu kegiatan di yayasan. Klien mengatakan tidak ada hambatan dalam berhubungan dengan orang lain karena klien mudah bergaul dan komunikasi.

Masalah keperawatan:-

\subsubsection{Spiritual}

a. Nilai dan Keyakinan : Klien beragama budha dan yakin dengan agamanya.

b. Kegiatan Ibadah :Ibadah 3 kali sehari. Yaitu pagi 1 kali, sekitar pukul 6 pagi dan pukul 1 siang, selanjutnya jam 8 malam.

\subsubsection{Status Mental}

a. Penampilan

Klien berpenampilan bersih, dan rapi

b. Pembicaraan

Klien masih mampu menjawab pertanyaan perawat dengan lambat namun dapat dipahami

c. Aktivitas Motorik

Klien terlihat sedikit gelisah

d. Suasana perasaan

Klien sedih jika melihat orang-orang tua lewat di depan yayasan tempat klien di rawat.

Masalah keperawatan :Harga Diri Rendah

e. Afek 
Afek klien labil, mudah emosi, mudah marah.

Masalah keperawatan :Risiko perilaku kekerasan

f. Interaksi selama wawancara

Klien kooperatif, ada kontak mata pada lawan bicara, mudah tersinggung dalam setiap interaksi.

g. Persepsi

tidak mendengar suara-suara aneh

h. Proses Pikir

Klien mampu menjawab apa yang ditanya dengan baik.

i. Isi pikir

Klien dapat mengontrol isi pikirnya,klien tidak mengalami gangguan isi pikir dan tidak ada waham.

j. Tingkat kesadaran

Klien tidak mengalami gangguan orientasi, klien mengenali waktu, orang dan tempat.

k. Memori

Klien mampu menceritakan kejadian di masa lalu dan yang baru terjadi.

1. Tingkat konsentrasi berhitung

Klien mampu berkonsentrasi dalam perhitungan sederhana tanpa bantuan orang lain.

m. Kemampuan penilaian

Klien dapat membedakan hal yang baik dan yang buruk.

n. Daya tilik diri

Klien tidak mengingkari penyakit yang diderita, klien mengetahui bahwa dia sering marah.

\subsection{Mekanisme Koping}

Klien mengalami mekanisme koping adaptif yaitu klien dapat berbicara baik dengan orang lain dan berkooperatif. 


\subsection{Masalah Psikososial dan Lingkungan}

Klien mengatakan sering mengikuti kegiatan di Yayasan tersebut.

\subsection{Pengetahuan Kurang Tentang Gangguan Jiwa}

Klien tidak mengetahui tentang gangguan jiwa yang di alaminya dan klien tau apa obat yang dikonsumsinya.

\subsection{Analisis Data}

\begin{tabular}{|l|l|c|}
\hline No & \multicolumn{1}{|c|}{ Data } & Masalah Keperawatan \\
\hline $\mathbf{1}$ & $\begin{array}{l}\text { Subjektif : } \\
\text { Klien mengatakan pernah melempar } \\
\text { barang-barang yang ada dirumahnya, } \\
\text { pernah memukul keluarganya dan marah- } \\
\text { marah kepada adik dan abangnya. }\end{array}$ & \multicolumn{1}{|c|}{$\begin{array}{c}\text { Risiko Perilaku } \\
\text { Kekerasan }\end{array}$} \\
$\begin{array}{l}\text { Objektif : } \\
\text { Klien tampak memandang orang lain } \\
\text { dengan tatapan bermusuhan dan tampak } \\
\text { gelisah. }\end{array}$ & $\begin{array}{l}\text { Subjektif : } \\
\text { Klien mengatakan dibuang oleh } \\
\text { keluarganya dan merasa minder dengan } \\
\text { orang lain karena di rawat diyayasan } \\
\text { pemenang jiwa }\end{array}$ & : Harga diri rendah \\
\hline $\begin{array}{l}\text { Objektif : } \\
\text { Klien tampak malu dan gelisah, dan } \\
\text { tanpak sedih saat di kaji }\end{array}$ & \\
\hline
\end{tabular}

\subsection{Daftar Masalah Keperawatan}
a. Risiko Perilaku Kekerasan
b. Gangguan Konsep Diri : Harga Diri Rendah 


\subsection{Pohon Masalah}

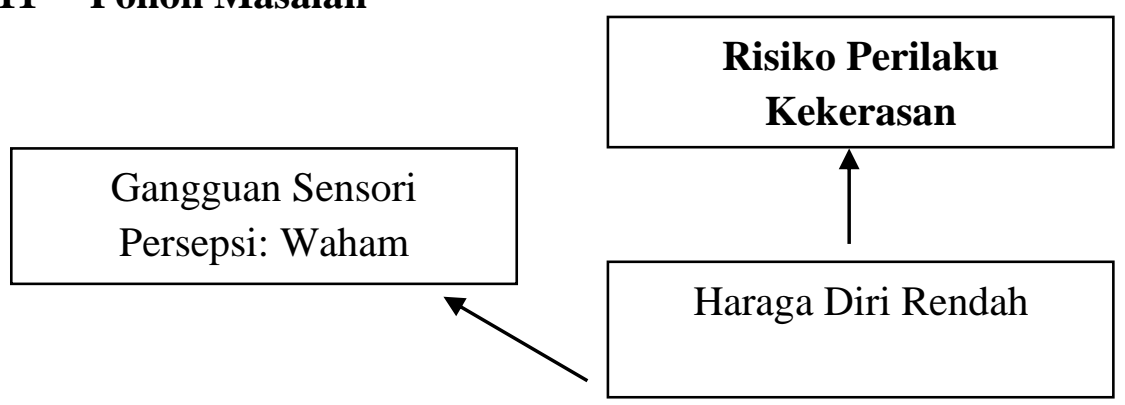

\subsection{Diagnosa Prioritas}

- Risiko Perilaku Kekerasan

\subsection{Intervensi Keperawata}

Tabel 3.2 Intervensi Keperawata

\begin{tabular}{|c|c|c|c|}
\hline $\begin{array}{c}\text { Diagnosa } \\
\text { Keperawatan }\end{array}$ & Tujuan & Kriteria Hasil & Intervensi \\
\hline \multirow[t]{4}{*}{$\begin{array}{l}\text { Risiko perilaku } \\
\text { kekerasan }\end{array}$} & $\begin{array}{l}\text { klien dapat } \\
\text { membina } \\
\text { hubungan saling } \\
\text { percaya }\end{array}$ & $\begin{array}{l}\text { Ketika di evaluasi } \\
\text { Klien mau membalas } \\
\text { salam, berjabat tangan, } \\
\text { menyebutkan nama, } \\
\text { tersenyum, ada kontak } \\
\text { mata,serta } \\
\text { menyediakan waktu } \\
\text { untuk kunjungan } \\
\text { berikutnya }\end{array}$ & $\begin{array}{l}\text { 1.1. Membina hubungan } \\
\text { saling percaya dengan } \\
\text { cara (menjelaskan } \\
\text { maksud dan tujuan } \\
\text { interaksi, jelaskan } \\
\text { tentang kontrak yang } \\
\text { akan dibuat, beri rasa } \\
\text { aman dan sikap } \\
\text { empati) } \\
\text { 1.2. Diskusikan bersama } \\
\text { klien tentang perilaku } \\
\text { kekerasan (penyebab, } \\
\text { tanda dan gejala, } \\
\text { perilaku yang muncul } \\
\text { dan akibat dari } \\
\text { perilaku tersebut). }\end{array}$ \\
\hline & $\begin{array}{l}\text { Klien dapat } \\
\text { mengendalikan } \\
\text { perilaku } \\
\text { kekerasan dengan } \\
\text { cara relaksasi } \\
\text { nafas dalam dan } \\
\text { pukul bantal kasur }\end{array}$ & $\begin{array}{l}\text { Klien mampu } \\
\text { menyebutkan dan } \\
\text { mendemonstrasi kan } \\
\text { cara } \\
\text { mengontrol perilaku } \\
\text { kekerasan dengan cara } \\
\text { relaksasi nafas dalam } \\
\text { dan pukul bantal }\end{array}$ & $\begin{array}{l}\text { Sp 1 } \\
\text { Latih klien } \\
\text { melakukan cara } \\
\text { mengontrol } \\
\text { Kemarahan: } \\
\text { 1.3. Ajarkan tehnik } \\
\text { relaksasi nafas } \\
\text { dalam } \\
\text { 1.4. Pukul bantal }\end{array}$ \\
\hline & $\begin{array}{l}\text { Klien dapat } \\
\text { mengendalikan } \\
\text { perilaku } \\
\text { kekerasan dengan } \\
\text { minum obat } \\
\text { secara teratur } \\
\end{array}$ & $\begin{array}{l}\text { Klien mampu } \\
\text { mengendalikan } \\
\text { perilaku kekerasan } \\
\text { dengan minum obat }\end{array}$ & $\begin{array}{l}\text { Sp 2: } \\
\text { Bantu klien mengontrol } \\
\text { perilaku kekerasan } \\
\text { pasien dengan minum } \\
\text { obat secara teratur }\end{array}$ \\
\hline & klien paham dan & Klien paham dan & Lakukan SP 3 pasien \\
\hline
\end{tabular}




\begin{tabular}{|l|l|l|l|}
\hline $\begin{array}{l}\text { mampu } \\
\text { mengendalikan } \\
\text { risiko perilaku } \\
\text { kekerasan dengan } \\
\text { cara berbicara } \\
\text { dengan baik }\end{array}$ & $\begin{array}{l}\text { mampu } \\
\text { menyampaikan } \\
\text { amarah dengan } \\
\text { cara berbicara } \\
\text { dengan baik }\end{array}$ & $\begin{array}{l}\text { risiko perilaku } \\
\text { kekerasan : Ajarkan } \\
\text { kepada klien bicara } \\
\text { yang baik bila sedang } \\
\text { marah. Ada tiga cara: } \\
\text { Meminta dengan } \\
\text { baik tanpa marah } \\
\text { Menolak dengan } \\
\text { baik } \\
\text { Mengungkapkan }\end{array}$ \\
& $\begin{array}{l}\text { Klien paham dan } \\
\text { mampu } \\
\text { mengendlikan } \\
\text { risiko perilaku } \\
\text { kekerasan dengan } \\
\text { cara } \\
\text { mempraktikan } \\
\text { cara spiritual } \\
\text { (beribadah }\end{array}$ & $\begin{array}{l}\text { Klien paham dan } \\
\text { mampu } \\
\text { mengendalikan } \\
\text { risiko perilaku } \\
\text { kekerasan dengan } \\
\text { cara beribadah }\end{array}$ & $\begin{array}{l}\text { Lakukan SP 4 pasien } \\
\text { risiko perilaku } \\
\text { kekerasan : Diskusikan } \\
\text { bersama klien cara } \\
\text { mengendalikan risiko } \\
\text { perilaku kekerasan } \\
\text { dengan cara beribadah. }\end{array}$ \\
\hline
\end{tabular}

\subsection{Implementasi Dan Evaluasi Keperawatan}

Tabel 3.3 Implementasi Dan Evaluasi Keperawatan

\begin{tabular}{|c|c|c|}
\hline Hari/tgl & Implementasi & Evaluasi \\
\hline $\begin{array}{l}\text { KAMIS } \\
\text { /18-3-2021 } \\
10: 30 \text { WIB }\end{array}$ & $\begin{array}{l}\text { 1. Data : } \\
\text { Tanda dan gejala : mudah marah- } \\
\text { marah, mudah tersinggung,tatapan } \\
\text { sinis, ,suka menyendiri, merasa } \\
\text { tidak dihargai } \\
\text { 2. Diagnosa Keperawatan } \\
\text { Risiko Perilaku Kekerasan } \\
\text { Harga Diri Rendah } \\
\\
\text { 3. Tindakan keperawatan: } \\
\text { Sp 1Risiko PerilakuKekerasan: } \\
\text { - Mengidentifikasi penyebab } \\
\text { risiko perilaku kekerasan yaitu } \\
\text { jika kemauan klien tidak } \\
\text { dituruti } \\
\text { - Mengidentifikasi tanda dan } \\
\text { gejala risiko perilaku kekerasan } \\
\text { yaitu klien marah, mengamuk } \\
\text { tanpa jelas, merusak barang- } \\
\text { barang, dan cenderung melukai } \\
\text { orang lain } \\
\text { - Menyebutkan cara mengontrol }\end{array}$ & $\begin{array}{l}\text { S : antusias dan bersemangat } \\
\text { O : } \\
\text { - } \text { Klien mampu } \\
\text { melakukan latihan fisik } \\
\text { tarik nafas dalam } \\
\text { dengan mandiri } \\
\text { - } \quad \text { Klien mampu pukul } \\
\text { kasur bantal dengan } \\
\text { mandiri } \\
\text { A : Risiko Perilaku kekerasan } \\
\text { (+) : Latihan fisik : } \\
\text { - Tarik nafas dalam 1x/ hari } \\
\text { - Pukul kasur bantal 1x/ } \\
\text { hari }\end{array}$ \\
\hline
\end{tabular}




\begin{tabular}{|c|c|c|}
\hline & $\begin{array}{l}\text { risiko perilaku kekerasan } \\
\text { adalah dengan latihan fisik 1: } \\
\text { tarik napas dalam latihan fisik } 2 \\
\text { : pukul kasur bantal } \\
\text { - } \text { Membantu klien latihan tarik } \\
\text { napas dalam dan pukul kasur } \\
\text { bantal. } \\
\text { 4. RTL: } \\
\text { Sp2 Risiko Perilaku Kekerasan: } \\
\text { - Mengontrol risiko perilaku } \\
\text { kekerasan dengan minum obat } \\
\text { secara teratur }\end{array}$ & \\
\hline $\begin{array}{l}\text { JUMAT } \\
\text { 19/3/2021 } \\
\text { 11:00 WIB }\end{array}$ & $\begin{array}{l}\text { 1. Data : } \\
\text { Tanda dan gejala : mudah marah- } \\
\text { marah, mudah tersinggung,tatapan } \\
\text { sinis, merasa tidak dihargai } \\
\text { Kemampuan : berjualan depan } \\
\text { rumah } \\
\text { 2. Diagnosa Keperawatan } \\
\text { Risiko Perilaku Kekerasan } \\
\text { Harga Diri Rendah } \\
\text { 3. Tindakan keperawatan: } \\
\text { Sp 2Risiko Perilaku Kekerasan } \\
\text { 1. Mengevaluasi kemampuan } \\
\text { klienuntuk tarik nafas dalam } \\
\text { dan pukul kasur bantal } \\
\text { 2. Memberikan informasi tentang } \\
\text { penggunaan obat } \\
\text { 4.RTL: } \\
\text { Sp } 3 \text { Risiko Perilaku Kekerasan } \\
\text { Komunikasi secara verbal: } \\
\text { Asertif/bicara baik-baik. }\end{array}$ & $\begin{array}{ll}\text { S : } & \text { senang dan antusias } \\
\text { O : } & \text { Klien mampu } \\
& \text { melakukan tarik nafas } \\
& \text { dalam dengan mandiri } \\
\text { - } & \text { Klin mampu pukul } \\
& \text { kasur bantal secara } \\
& \text { mandiri } \\
\text { - } & \text { Klien mampu ke poli } \\
& \text { jika merasa kumat dan } \\
& \text { meminum obat secara } \\
& \text { teratur dengan bantuan } \\
& \text { perawat } \\
\text { A : } & \text { Risiko Perilaku kekerasan } \\
(+) & \\
\text { P : } & \\
\text { - } & \text { Latihantarik nafas dalam } \\
& \text { 1 x/hari } \\
\text { - } & \text { Latihan pukul kasur } \\
& \text { bantal 1 x/hari } \\
\text { - } & \text { berobat }\end{array}$ \\
\hline
\end{tabular}




\begin{tabular}{|c|c|c|}
\hline $\begin{array}{l}\text { Jumat } \\
\text { 19/3/2021 } \\
\text { 10:00 WIB }\end{array}$ & $\begin{array}{l}\text { 1. Data: } \\
\text { Tanda dan gejala : mudah marah- } \\
\text { marah, mudah tersinggung,tatapan } \\
\text { sinis, merasa tidak dihargai } \\
\text { Kemampuan : memasak air } \\
\text { 2. Diagnosa Keperawatan: } \\
\text { Risiko Perilaku Kekerasan } \\
\text { Harga Diri Rendah } \\
\text { 3. Tindakan keperawatan: } \\
\text { Sp 3Risiko Perilaku Kekerasan } \\
\text { - Mengevaluasi kemampuan } \\
\quad \text { klien untuk tarik nafas dalam } \\
\quad \text { dan pukul kasur bantal } \\
\text { - Minum obat } \\
\text { - Komunikasi secara verbal : } \\
\quad \text { asertif/bicara baik-baik } \\
\text { 4.RTL: } \\
\text { Sp } 4 \text { Risiko Perilaku Kekerasan: } \\
\text { - Spritual : Beribadah }\end{array}$ & $\begin{array}{ll}\text { S : } & \text { senang } \\
\text { O : } & \\
- & \text { Klien mampu melakukan } \\
& \text { komunikasi secara verbal : } \\
& \text { asertif/bicara baik- } \\
& \text { baikdengan motivasi } \\
\text { A : } & \text { RisikoPerilaku kekerasan } \\
(+) & \\
\text { P : } & \\
\text { - } & \text { Latihan tarik nafas } \\
& \text { dalam dan pukul kasur } \\
& \text { bantal 1x/hari } \\
\text { - } & \text { Berobat a melakukan } \\
\text { - } & \text { Klien secara } \\
& \text { komunikasi r asertif/bicara } \\
& \text { verbal : } \\
& \text { baik-baik }\end{array}$ \\
\hline $\begin{array}{l}\text { SABTU } \\
\text { 20/3/2021 } \\
11: 00 \mathrm{WIB}\end{array}$ & $\begin{array}{l}\text { 1. Data: } \\
\text { Tanda dan gejala : mudah marah- } \\
\text { marah, mudah tersinggung,tatapan } \\
\text { sinis, merasa tidak dihargai } \\
\text { Kemampuan : berjualan } \\
\text { 2. Diagnosa Keperawatan: } \\
\text { Risiko Perilaku Kekerasan } \\
\text { Harga Diri Rendah } \\
\text { 3.Tindakan keperawatan: } \\
\text { Sp 4Risiko Perilaku Kekerasan } \\
\text { - Mengevaluasi kemampuan } \\
\text { klien dalam tarik nafas dalam } \\
\text { dan pukul kasur bantal, minum } \\
\text { obat secara teratur dan bicara } \\
\text { baik-baik. } \\
\text { - Melatih klien untuk } \\
\text { melaksanakan kegiatan } \\
\text { spiritual yang sudah diatur. } \\
\text { RTL : } \\
\text { Risiko Perilaku Kekerasan : Follow up } \\
\text { dan evaluasi SP 1-4 risiko Perilaku } \\
\text { Kekerasan }\end{array}$ & $\begin{array}{ll}\text { S : } & \text { senang } \\
\text { O : } & \text { Klien mampu } \\
& \text { melaksanakan kegiatan } \\
& \text { ibadah dengan baik } \\
& \text { misalnya Sholat } \\
& \\
\text { A : } & \text { Perilaku kekerasan (+) } \\
\text { P: } \quad & \\
- & \text { Latihan tarik nafas } \\
& \text { dalam dan pukul kasur } \\
& \text { bantal 2x/hari } \\
- & \text { Berobat } \\
- & \text { Latihan melakukan } \\
& \text { komunikasi secara } \\
& \text { verbal : asertif/bicara } \\
& \text { baik-baik } \\
\text { - } & \text { Latihan klien untuk } \\
& \text { melaksanakan kegiatan } \\
& \text { spiritual yang sudah } \\
& \text { diatur. }\end{array}$ \\
\hline
\end{tabular}




\section{BAB 4}

\section{PEMBAHASAN}

Setelah penulis melaksanakan asuhan keperawatan kepada Tn.K dengan Risiko Perilaku Kekerasan di Yayasan pemenangan Jiwa, maka penulis pada $\mathrm{BAB}$ ini akan membahasan kesenjangan antara teoritis dengan tinjauan kasus. Pembahasan dimulai melalui tahapan proses keperawatan yaitu pengkajian, diagnosa keperawatan, perencanaan, pelaksanaan dan evaluasi.

\subsection{Tahap Pengkajian}

Selama pengkajian dilakukan pengumpulan data dari beberapa sumber yaitu dari pasien dan pengawas yayasan. Mahasiswa mendapat sedikit kesulitan dalam menyimpulkan data karena keluarga pasien jarang mengkunjungi pasien di yayasan pemenang jiwa. Maka mahasiwa melakukan pendekatan pada pasien melalui komunikasi terapeutik yang lebih terbuka membantu pasien untuk memecahkan perasaannya dan juga melakukan observasi kepada pasien. Adapun upaya tersebut yaitu :

a. Melakukan pendekatan dan membina hubungan saling percaya diri pada pasien agar pasien lebih terbuka dan lebih percaya dengan menggunakan perasaan.

b. Mengadakan pengkajian pasien dengan wawancara dan tidak menemukan kesenjangan karena di temukan hal sama seperti diteori bahwasanya Perilaku kekerasan merupakan respon maladaptif dari kemarahan, hasil dari kemarahan yang ekstrim ataupun panik. Perilaku kekerasan yang timbul pada klien skizofrenia diawali dengan adanya perasaan tidak berharga, takut,dan ditolak oleh lingkungan sehingga individu akan menyingkir dari hubungan interpersonal dengan oran lain (Pardede, Keliat \& Yulia, 2015).

\subsection{Tahap perencanaan}

Perencanaan dalam proses keperawatan lebih dikenal dengan rencana asuhan keperawatan yang merupakan tahap selanjutnya setelah pangkajian dan penentuan diagnosa keperawatan. Pada tahap perencanaan penulis 
hanya menyusun rencana tindakan keperawatan sesuai dengan pohon masalah keperawatan yaitu :perilaku kekerasan. Pada tahap ini antara tinjauan teoritis dan tinjaun kasus tidak ada kesenjangan sehingga penulis dapat melaksanakan tindakan seoptimal mungkin dan didukung dengan seringnya bimbingan dengan pembimbing. Secara teoritis digunakan cara strategi pertemuan sesuai dengan diagnosa keperawatan yang muncul saat pengkajian. Adapun upaya yang dilakukan penulis yaitu :

1. Risiko Perilaku Kekerasan

a. Mengidentifikasi isi Risiko Perilaku Kekerasan

b. Mengidentifikasi waktu terjadi Risiko Perilaku Kekerasan

c. Mengidentifikasi situasi pencetus Risiko Perilaku Kekerasan

d. Mengidentifikasi respon terhadap Risiko Perilaku Kekerasan

e. Membantu pasien mempraktekan latihan cara mengontrol Risiko Perilaku Kekerasan dengan tarik napas dalam dan pukul kasur bantal

f. Menjelaskan cara mengontrol perilaku kekerasan dengan minum obat

g. Melatih pasien mengontrol Risiko Perilaku Kekerasan dengan berbicara baik-baik dengan orang lain dan spritual

h. Mengevaluasi jadwal kegiatan harian pasien

\subsection{Tahap Implementasi}

Pada tahap implementasi, penulis hanya mengatasi 1 masalah keperawatan yakni: diagnosa keperawatan Risiko Perilaku Kekerasan dikarenakan masalah utama yang dialami klien. Pada diagnosa keperawatan Risiko Perilaku Kekerasandilakukan strategi pertemuan yaitu mengidentifikasi Perilaku Kekerasan, mengontrol perilaku kekerasan dengan cara tarik napas dan pukul kasur bantal. Strategi pertemuan yang kedua yaitu anjurkan minum obar secara teratur, strategi pertemuan ketiga yaitu latihan dengan cara komunikasi secara verbal atau bicara baik-baik strategi pertemuan ke empat yaitu Spritual. 


\subsection{Tahap Evlaluasi}

Pada tinjauan teoritis evaluasi yang diharapkan adalah :

1. Pasien mempercayai perawat sebagai terapis

2. Dapat mengidentifikasi dan mengontrol Risiko Perilaku Kekerasan

3. Dapat mengendalikan Risiko Perilaku Kekerasan melalui latihan fisik,

4. Dapat mengendalikan Risiko Perilaku Kekerasan dengan cara minum obat secara teratur

5. Dapat mengendalikan Risiko Perilaku Kekerasan dengan berbicara baik-baik

6. Dapat mengendalikan Risiko Perilaku Kekerasan dengan spritual yang terjadwal.

Pada tinjauan kasus evaluasi yang dihasilkan adalah :

1. Klien sudah dapat mengontrol dan mengidentifikasi Risiko Perilaku Kekerasan

2. Klien dapat mengendalikan Risiko Perilaku Kekerasan melalui latihan fisik

3. Klien dapat mengendalikan Risiko Perilaku Kekerasan dengan cara pergi ke poli jiwa untuk mendapatkan minum obat

4. Klien dapat mengendalikan Risiko Perilaku Kekerasan dengan berbicara baik-baik dengan orang lain

5. Klien dapat mengendalikan Risiko Perilaku Kekerasan dengan melakukan spritual terjadwal. 


\section{BAB 5}

PENUTUP

\subsection{Kesimpulan}

1. Setelah menguraikan tentang proses keperawatan pada Tn.K dan disimpulkan bahwa pasien dapat mengontrol risiko perilaku kekerasan dengan terapi yang di ajarkan oleh mahasiwa. Dimana pasien dapat melakukan tarik nafas dalam, memukul bantal secara mandiri untuk mengontrol amarahnya. Pasien juga minum obat secara teratur dan berbicara secara baik-baik jika ingin meminta sesuatu atau melakukan penolakan, hingga pasien dapat melakukan spritual sesuai ajaran agama yang dianut.

\subsection{Saran}

1. Diharapkan pada keluarga sering mengunjungi pasien selama waktu perawatan karena dengan seringnya keluarga berkunjung, maka pasien merasa berarti dan dibutuhkan dan juga setelah pulang keluarga harus memperhatikan obat dikonsumsi.

2. Bagi mahasiswa/mahasiwi agar lebih memperdalam ilmu pengetahuan khusus tentang keperawatan jiwa. 


\section{DAFTAR PUSTAKA}

1. Azis, N. R., Sukamto, E., \& Hidayat, A. (2018). Pengerun Terapi De-Ekslasi Terhadap Perubahan Perilaku Pasien dengan Resiko Perilaku Kekerasan di Rumah Sakit Jiwa Daerah Atma Husada Mahakam Samarinda. http://repository.poltekkeskaltim.ac.id/id/eprint/797

2. Depkes, R.I., (2015) Hasil Riskesdas 2015 Departemen Kesehatan Republik Indonesia http://www.depkes .go.id/resource/download/general.

3. Pardede, J. A., Siregar, L. M., \& Hulu, E. P. (2020). Efektivitas Behaviour Therapy Terhadap Risiko Perilaku Kekerasan Pada Pasien Skizofrenia Di Rumah Sakit Jiwa Prof. Dr. Muhammad Ildrem Provsu Medan. Jurnal Mutiara Ners, 3(1), 8-14. http://114.7.97.221/index.php/NERS/article/ view/1005

4. Pitayanti, A., \& Hartono, A. (2020). Sosialisasi Penyakit Skizofrenia Dalam Rangka Mengurangi Stigma Negatif Warga di Desa Tambakmas Kebonsari-Madiun. Journal of Community Engagement in Health,3(2), 300-303. https://jceh.org/index.php/JCEH/article/view/83/78

5. Dwi P.F., \& Arum, S. K. (2017). Mekanisme Koping Pada Pasien Perilaku Kekerasan Dengan Risiko Menciderai Orang Lain Dan Lingkungan (Doctoral dissertation, Universitas Muhammadiyah Surakarta). $\underline{\text { http://eprints.ums.ac.id/id/eprint/52420 }}$

6. Hastuti, R. Y., \& Setianingsih, S. (2016). Pengaruh Cognitive Behaviour Therapy Pada Klien Dengan Masalah Keperawatan Perilaku Kekerasan Dan RPK Di Rsjd.

7. Keliat B, dkk. (2014). Proses Keperawatan Jiwa Edisi II. Jakarta : EGC

8. Keliat, B.A \& Akemat (2016). Keperawatan jiwa : terapi Aktivitas kelompok. Ed.2. EGC

9. Kemenkes RI. (2019). Riset Kesehatan Dasar, RISKESDAS.Jakarta: Kemenkes RI. https://databoks.katadata.co.id/datapublish/2019/10/08/persebaran-prevalensiskizofreniapsikosis-di-indonesia\#

10. Pardede, J. A. (2020, November 12). Standar Asuhan Keperawatan Jiwa Dengan Masalah Risiko Perilaku Kekerasan. https://doi.org/10.31219/osf.io/we7zm

11. Pardede, J. A, Keliat, B.A \& Wardani,I.Y. (2013). Pengaruh Acceptance And Commitment Therapy Dan Pendidika n Kesehatan Kepatuhan Minum Obat Terhadap Gejala, Kemampuan Berkomitmen Pada Pengobatan Dasar Kepatuhan Pasien Skizofrenia. Depok, Tesis. FIK UI

12. Sulistiowati, N. M. D., Keliat, B. A., \& Wardani, I. Y. (2014). Pengaruh acceptance and commitment therapy terhadap gejala dan kemampuan klien dengan resiko perilaku kekerasan. Jurnal Keperawatan Jiwa, 2(1), 51-57. https://doi.org/10.26714/jkj.2.1.2014.51-57 
13. Widyastini, B.I. (2014). Pengaruh Terapi Aktivitas Kelompok : Stimulasi Persepsi Sesi I - V Terhadap Kemampuan Mengontrol dan Mengekspresikan Marah Pada Pasien Risiko Perilaku Kekerasan di RSJD Dr. Amino Gondohutomo Semarang. Jurnal mahasiswa bidang ilmu keperawatan. 1 (1) 2014. http://112.78.40.115/ejournal/index.php/ilmukeperawatan/article/view/54

14. Pardede, J. A., \& Laia, B. (2020). Decreasing Symptoms of Risk of Violent Behavior in Schizophrenia Patients Through Group Activity Therapy. Jurnal Ilmu Keperawatan Jiwa, 3(3),291-300. http://dx.doi.org/10.32584/jikj.v3i3.621

15. Prastya, D. F., \& Pratiwi, A.S. K. (2017). Mekanisme Koping Pada Pasien Perilaku Kekerasan Dengan Risiko Menciderai Orang Lain Dan Lingkungan. Sikripsi, Universitas Muhammadiyah Surakarta. http://eprints.ums.ac.id/id/eprint/52420

16. Pardede, J. A., Simanjuntak, G. V., \& Laia, R. (2020). The Symptoms of Risk of Violence Behavior Decline after Given Prgressive Muscle Relaxation Therapy on Schizophrenia Patients. Jurnal Ilmu Keperawatan Jiwa,3(2), 91-100. http://dx.doi.org/10.32584/jikj.v3i2.534

17. Pardede, J. A., Siregar, L. M., \& Halawa, M. (2020). Beban dengan Koping Keluarga Saat Merawat Pasien Skizofrenia yang Mengalami Perilaku Kekerasan. Jurnal Kesehatan, 11(2), 189-196. http://dx.doi.org/10.26630/jk.v11i2.1980

18. Suryanti., Cannity, K., McIndoo, C. C., File, A. A., Ryba, M. M., Clark, C. G., \& Bell, J. L. (2018). Behavior Therapy for depressed breast cancer patients: Predictors of treatment outcome. Journal of Consulting and Clinical Psychology

19. WHO (2019). Schizophrenia. Retrieved from. https://www.who.int/news-room/factsheets/\%20detail/schizophrenia

20. Pardede, J. A, sirait, D. Riandi, R, Emanuel, P \& Laia R. (2016). Ekspresi emosi keluarga dengan frekuensi kekambuhan pasien skizofrenia. Idea Nursing Journal, $7(3), 53-61$

21. Pardede, J. A., Keliat, B.A., \& Yulia, I. (2015). Kebutuhan Dan Komitmen Klien Skizofrenia Meningkat Setelah Diberkan Acceptance And Commitment Therapy Dan Pendidikan Kesehatan Kepatuhan Minum Obat. Jurnal Keperawatan Indonesia, 3(18), 157-166. http://dx.doi.org/10.7454/jki.v18i3.419

22. Parwati, I. G., Dewi, P. D., \& Saputra, I. M. (2018). Asuhan Keperawatan Perilaku Kesehatan. https://www.academia.edu/37678637/ asuhan_keperawatan_perilaku_kekerasan

23. Riskesdas (2018) Hasil Utama riskesdas 2018 Kementrian Kesehatan Badan Penelitian dan Pengembangan Kesehatan.

24. Suryenti, V. (2017). Dukungan Dan Beban Keluarga Dengan Kemampuan Keluarga Merawat Pasien Resiko Perilaku Kekerasan Di Klinik Jiwa Rumah Sakit Jiwa Provinsi Jambi Tahun 2017. Jurnal Psikologi Jambi, 2(2), 39-46. https://www.onlinejournal.unja.ac.id/jpj/article/view/4795 
25. Yusuf, AH. (2015) Buku Ajar Keperawatan Kesehatan Jiwa. Jakarta Selatan : Salemba Medik.

26. Pardede, J. A., \& Ramadia, A. (2021). The Ability to Interact With Schizophrenic Patients through Socialization Group Activity Therapy. International Journal of Health Science and Medical Research, 1(1), 06-10. http://ijhsmr.com/index.php/ijhsmr/article/view/6

27. Manao, B. M., \& Pardede, J. A. (2019). Correlation of Family Burden of The Prevention of Recurrence of Schizophrenia Patients. Mental Health, 4(1), 31-42.

28. Sahputra, A. (2021). Asuhan Keperawatan Jiwa Pada Tn. S Dengan Risiko Perilaku Kekerasan. 10.31219/osf.io/j6ewu 